\title{
ETIOLOGICAL ASPECTS OF GASTRO-ENTERITIS
}

\author{
PART II \\ BY \\ E. HINDEN, M.D., M.R.C.P.
}

Classification of enteritis presents many difficulties. On this subject, Paterson (1933a) said, 'The more one studies the problem of the diarrhoeal disease of infancy, the more complicated it appears '; this same writer (1944) divides gastro-enteritis into three main groups: infective, dietetic, and symptomatic. The first group, which is better called specific, is due to an infection by a known pathogen, such as the Gram-negative bacilli of the coli-typhoiddysentery group. A sub-group of this is the diarrhoea caused by specific infection of other abdominal organs, such as pelvic peritonitis or tuberculous mesenteric adenitis. The second group is due to gross errors in feeding, and is becoming less common nowadays, as correct knowledge of infant feeding extends through the community. The third group, the commonest, is thought to be due to infection in the body outside the abdomen; this is the 'parenteral type.' Campbell and Cunningham (1941) prefer to call this last group 'alimentary-infectious complex, with or without parenteral infection.' This latter name, though vague, seems better than 'parenteral diarrhoea' in that it recognizes the existence of infection directly influencing the alimentary system and places parenteral infection as a concomitant, rather than a causative disorder.

In this series, ten infants only, out of the total of 148 were suffering from gross dietetic errors; seven recovered and three died. There were but two cases in the 'specific infection' group: one was suffering from a Salmonella infection, the other from B. dysenteriae Sonne. Each of these had another infection (one respiratory, one dermatitis) and were classed as 'parenteral' on admission. Two infants who presented as frank dysentery, and eleven who were involved in a small S. aetrycke outbreak (Hinden, 1940) have not been included. It will be seen that the bulk of the patients-136 out of 148 were suffering from 'alimentary infectious' diarrhoea, and of these sixty-six, roughly half, had some form of parenteral infection. These figures will be more fully discussed later, when the relation of parenteral infection to diarrhoea is dealt with. Advances in classification will come through splitting off specific types of illness from this 'omnibus' group.

\section{Route of Invasion}

Accepting, then, that there is infection, enteral or parenteral, what is the route of invasion? The mouth suggests itself; but the utmost care in sterilizing feeds and feeding apparatus does not limit an epidemic. Felsen and Wolarsky (1942) concluded that "The mode of transfer is from " mouth-to-mouth," rather than from " intestineto-mouth " as is the case with the primary enteric pathogens.' It is noteworthy, too, that wholly breast-fed infants do contract this disease, albeit in small numbers. Feibush (1945) described an epidemic of enteritis in New York, which was highly infectious and attacked individuals of all ages. The onset of the disease was regularly preceded by a sore throat, and the author expresses his opinion that the respiratory channels were the route of entry. This is not the gastro-enteritis of infancy, but it may be a near relative.

\section{Bacteriology}

The bacteriology of this disease has been intensively studied, and a bewildering array of pathogens suggested. The noxious agents implicated fall into three groups, the Gram-negative bacilli, other bacteria, and viruses. In the first group, the known pathogens, the food-poisoning (Salmonella) and dysentery (Shigella) families have to be considered; but they are common in warm climates. Ouyang (1940) reported from China that he found a pathogen (usually Shigella) in 63 per cent. of 190 cases; Moore and Dennis (1940) in the Lebanon isolated a pathogen (bacterial or protozoal) in 50 per cent. of cases under one year old, and in 66 per cent. under two years old; in nearby Palestine Meyer (1943) considered that half his cases of summer diarrhoea were due to Shigella infections; in Montevideo Hormaeche et al. (1943) analysed 668 cases of enteritis, and found Shigella responsible for 39 per cent. of cases, Salmonella for 23 per cent.; and in a recent study from Ohio, Weihl et al. (1947) reported finding a dysentery organism in 18.5 per cent. of 221 cases.

In temperate climates, however, it is rare to isolate a pathogen. Bloch (1941) writing of 
diarrhoeal diseases in Glasgow, found that of 908 dysenteries, only 3.3 per cent. were under one year of age; paratyphoid and typhoid fevers also were uncommon in this age-group. Evans (1942) found that most of the cases of hospital diarrhoea in older children and adults were due to known pathogens, but it was not so with the young children; and no pathogen was isolated from any of his six fatal cases. Crowley et al. (1941) found no evidence of abnormal organisms, of soluble toxins, or of poisons formed in the maternal breast. Abt and Abt (1944) agree with Bloch (1941) that enteric fevers are rare in childhood, but Neter and Clark (1944b) write, ' the importance of paratyphoid bacilli as incitants of diarrhoeal disease in infants and children is stressed.' Considering other Salmonella organisms, Neter (1944) reports some sporadic outbreaks due to S. typhi murium and Abramson et al. (1939) describe four cases in neonates.

There is evidence that occasionally the physiological commensals of the coli groups are concerned in the pathogenesis of this disease. Blacklock et al. (1937) pointed out that normally B. coli is absent from the upper bowel, but that it invaded this region in parenteral infections, and was found most frequently in primary gastro-enteritis. This may be related to the diminished gastric and enteric secretions found in such infections. But their work does not decide whether the presence of $B$. coli in this unusual situation causes the enteritis, or results from it. The theory that infantile gastro-enteritis is due to an 'endogenous' infection is an attractive one, and is supported by Marriott (1944) and Cruickshank $(1945,1946)$; but it does not account for the extreme infectivity of the disease. The paracolon bacilli are in a slightly different category; they are only occasionally found in the normal individual, and their significance is still obscure. Anderson and Nelson (1944) isolated a paraaerogenes paracolon bacillus in one epidemic, but are doubtful whether it was of etiological importance. McClure (1943), describing four outbreaks of epidemic neonatal diarrhoea, writes, 'Haemolytic colon organisms show a much greater incidence in infants with epidemic diarrhoea than in well infants in the same nursery.' He tried to reproduce the disease experimentally in cats, but with inconclusive results. Neter and Clark (1944a) sum up, 'The role played by paracolon bacilli in diarrhoeal diseases remains obscure.'

Other bacteria also have been accused of causing gastro-enteritis. Neter and Farrar (1943) discuss the importance of Proteus vulgaris and P. morgani, but come to no definite conclusion; Walcher (1946) isolated B. mucosus capsulatus (Friedländer's group) from a small epidemic in a babies' home; Staph. aureus has been blamed in the U.S.A. by Felsen and Wolarsky (1942), and in Australia by Draper and Brown (1946); Sakula (1943) blames Ps. pyocyanea for the epidemic he describes, and Cron et al. (1940) report an epidemic caused by a haemolytic streptococcus.
It seems, then, that many organisms are occasionally responsible for an outbreak of gastro-enteritis, but Fothergill (1944) sums up by saying, 'In spite of such researches, there remain a large number of instances of summer diarrhoea in which the etiology is obscure.'

\section{Possibility of Virus Causation}

The possibility that gastro-enteritis of infants, and especially of neonates, may be due to a virus has been discussed many times. Campbell and Cunningham (1941) consider that a virus might be the cause of some at least of their 'alimentaryinfectious' group. Both Crowley et al. (1941) and Bloch (1941) consider that the epidemics they describe were due to viruses. It is interesting that in this latter epidemic, onset was usually with rhinitis. Lyon and Folsom (1941) discuss 'epidemic diarrhoea of the newborn,' and, after excluding all cases with general sepsis, obvious systemic disease, and bacillary dysentery, consider the others to be due to a virus, possibly akin to the influenza virus. They discovered the interesting fact that citrated whole blood from convalescing influenza patients was markedly effective in treatment, while ordinary blood was useless. They also point out that the conception of 'parenteral diarrhoea' only became current after the great influenza pandemic, and speculate whether this disorder is not merely the form taken by influenza in the very young. Gunn (1944a) also considers that an influenza-like virus might be an important pathogen in gastro-enteritis. Dr. G. B. Ludlam (Dept. of Health for Scotland, 1947) gives a more recent opinion: 'A virus has been implicated in several epidemics, but the etiology of this condition cannot be regarded as settled.'

Viral diarrhoea in adults has attracted much attention of recent years, on both sides of the Atlantic. Typical descriptions have been given by Brown et al. (1945) in this country and by Feibush (1945) in New York. Discussing this disease, Reimann (1944) writes, 'It is unknown at present whether or not the disease is related to the severe epidemic diarrhoeal disease of unknown cause which affects new-born infants in nurseries.' A good account of the clinical features is given by Reimann, Hodges, and Price (1945) and of the bacteriology by Reimann, Price, and Hodges (1945); they conclude, "These results . . . suggest that the causative agent of the disease is filtrable, airborne, enters through the respiratory tract, and is present in the oropharynx and stool but not in the blood.'

These last authors produce good evidence of the viral nature of adult epidemic diarrhoea. There is also direct evidence implicating a virus in infantile gastro-enteritis Light and Hodes (1943), after vainly attempting to infect the usual small laboratory animals, finally succeeded with calves. Here are their conclusions:

1. In connexion with four separate epidemics 
of diarrhoea of the newborn, a filter-passing agent has been isolated which regularly produces diarrhoea in calves.

- 2 . In the attempts so far made, this agent has not been isolated from the stools of normal infants or normal calves.

'3. The evidence suggests, though it is not conclusive, that the agent may be a cause of epidemic diarrhoea of the newborn.'

In 1944, Buddingh and Dodd described an epidemic of diarrhoea associated with stomatitis. From all forty-five sore mouths tested, and from all twelve bad stools examined, a virus was extracted which produced keratitis in experimental animals. The high infectivity of this diarrhoea, and the clinical description they furnish, are indistinguishable from those associated with hospital epidemic diarrhoea. They make the interesting point that adults may be, or become through contact, temporary carriers of the virus. Evans (1942) dealing with hospital diarrhoea, noticed that during the attacks of non-specific diarrhoea in young infants, there were always coughs and colds about in the ward, often only in the older children who did not suffer from diarrhoea. Buddingh (1946) has since found this virus in ten epidemics of neonatal diarrhoea. On balance, there seems to be at least as much evidence indicating a viral cause, as a bacterial, in gastro-enteritis of temperate climates.

\section{Pathology}

The pathological changes found post-mortem have been described by several of the writers already cited. The most nearly constant lesions have been found in the intestine, regional lymph glands, and the liver. The mucous membrane of the intestine has shown all changes from a mild congestion to active ulceration; both the mesenteric glands and Peyer's patches have been found swollen and hyperaemic. Parenchymatous degeneration of the liver is very common; this toxic change has also been noted in the kidneys and heart. Acute oedema of the brain, at times with haemorrhages and with flattening of the convolutions, has also been reported. The findings point to an acute infection falling on the intestine followed by spread along the intestinal lymphatic and vascular channels. Sakula (1943) however, considered that his patients died of acute toxaemia, rather than of intestinal infection. Morbid changes in other organs are usually found: pneumonia, otitis, and mastoiditis.

In the present series, twenty-two autopsies were performed. In nine of them no gross changes were found; in the other thirteen there were naked-eye morbid changes (microscopic examinations were but rarely carried out). In ten cases the intestine was found affected: the degree varied from thinning and ballooning of the small intestine to ulceration and necrosis of the mucous membrane. Fatty change in the liver was observed five times; inflammation of the regional lymph-glands four times. Rarer changes were congestion of spleen and cloudy swelling of kidney, necrosis of wall of gallbladder, and a peritonitis due to B. coli and Ps. pyocyanea. Here again, the evidence points to the brunt of the infection falling on the intestine, and spreading thence by the lymphatic and portal circulations.

\section{'Parenteral Infection'}

The problem of the relationship of "parenteral infection' to infantile diarrhoea is an important and a difficult one. The observation that infants suffering from diarrhoea also frequently suffer from an infection outside the alimentary canal (such as pneumonia, otitis media and mastoiditis, and septic dermatitis) is unquestioned; but whether this parenteral infection causes the diarrhoea, results from the diarrhoea, or has no causal relationship, is not yet decided. It has been widely held, in this country at any rate, that it is causative; but authoritative opinion can be found for the other views as well.

Evans (1942) considers parenteral infection, especially respiratory, to be an important factor; he found it in every outbreak of non-specific diarrhoea he studied. Alexander and Eiser (1944) found parenteral infection (the bulk of it respiratory) in 124 out of 140 cases studied; they, too, think it an important factor. Gunn (1944a) found mastoiditis the most frequent post-mortem lesion, and thinks it important to treat this disease, even though he is not sure whether it is really causative. Smellie (1939) also was impressed by the frequent association of mastoiditis and severe gastroenteritis, but finally gives this cautious judgment: - The relationship between infantile diarrhoea and parenteral infection has not yet been elucidated. It is suggested that sometimes this infection is the cause, but sometimes it is the consequence.'

The view that the parenteral infection may be the result of the diarrhoea is supported by Fothergill (1944), who writes: "In infants and children the most common complication of dysentery is an intercurrent infection. Infection of the upper respiratory passages and otitis media are fairly common.' Ouyang (1940), in his series of (mainly bacillary) enteritis, found bronchopneumonia the most common complication, and Frant and Abramson (1939) found pulmonary and otitic disease the most serious complication of epidemic diarrhoea of the newborn. Neter (1944) found the same complication in infants suffering from specific Salmonella infections: it is hard to see that parenteral infection could be responsible for that. It is possible that the frequent vomiting which is a feature of gastro-enteritis may cause bronchopneumonia and otitis by trickling into the trachea and upper respiratory passages; though Gunn (1946) points out that these complications are rare in non-infective, obstructive vomiting, as in pyloric stenosis.

The neutral view also does not lack support. In her review of over 200 cases, Gairdner (1945) found that 35 per cent. of hercases had parenteral infection, but that this made no difference to the outcome, and she is doubtful whether there is any causal 
relation. In 1933(b), Paterson wrote: ' The author frankly confesses that he does not understand why an infant with a nasopharyngitis or an otorrhoea, a mastoiditis or a furunculosis, or an infection in some part of the body remote from the intestine, should tend to have diarrhoea.' Mitman (1944) agrees: 'In my experience parenteral infections are found in about 30 per cent. only of cases, and proof is lacking that they are causal.' Some recent American investigators (Weihl et al., 1947) report that in their series diarrhoea was mild when associated with parenteral infection, and they consider that there is no causal relation between the two.

An analysis of the present series to show the effect of parenteral infection is shown in table 7. Parenteral infection is classified into three groups: Upper respiratory infection, of the larynx and above, including otitis and mastoiditis; lower respiratory infection, of the trachea and below, most being pneumonia; and skin infections, comprising impetigo, scabies, and infected eczema.

TABUE 7

ANALYSIS OF PARENTERAL INFECTIONS IN INFANTS SUFFERING FROM GASTRO-ENTERITIS

\begin{tabular}{|c|c|c|c|c|}
\hline & \multicolumn{2}{|c|}{$\begin{array}{l}\text { Contracted } \\
\text { in hospital }\end{array}$} & \multicolumn{2}{|c|}{$\begin{array}{l}\text { Contracted } \\
\text { outside }\end{array}$} \\
\hline $\begin{array}{l}\text { With parenteral infection: } \\
\text { upper respiratory } \\
\text { lower respiratory } \\
\text { of the skin }\end{array}$ & $\begin{array}{c}\text { Recovered } \\
25 \\
5 \\
14 \\
6\end{array}$ & $\begin{array}{c}\text { Died } \\
27 \\
6 \\
16 \\
5\end{array}$ & $\begin{array}{c}\text { Recovered } \\
28 \\
16 \\
9 \\
3\end{array}$ & $\begin{array}{c}\text { Died } \\
6 \\
3 \\
2 \\
1\end{array}$ \\
\hline $\begin{array}{l}\text { Without parenteral } \\
\text { infection: } \\
\text { not doing well }, \ldots \\
\text { post-operative } \\
\text { others } \quad . .\end{array}$ & $\begin{array}{l}6 \\
1 \\
\overline{5}\end{array}$ & $\begin{array}{r}19 \\
10 \\
1 \\
8\end{array}$ & $\frac{32}{32}$ & $\begin{array}{r}13 \\
\overline{1} \\
12\end{array}$ \\
\hline
\end{tabular}

The distinction between infants catching the disease in hospital, and those acquiring it outside, has been maintained, with the corrections made for relapses and for recent discharge, as mentioned previously. The table shows a number of interesting features:
1. The case mortality for gastro-enteritis with parenteral infection is 52 per cent. in hospital infection, 18 per cent. in outside cases; in either case it is lower than the case mortality without parenteral infection, when the rates are 76 per cent. and 29 per cent. (however, the figures for outside cases are not statistically significant). This agrees with the American opinion, quoted above, that enteritis with parenteral infection tends to be milder.

2. Of the seventy-seven hospital cases, fifty-two, that is 68 per cent., had a parenteral infection; while only thirty-four out of seventy-nine, that is 43 per cent., of the outside cases had this complication. This difference is significant. The trend of the figures might have been anticipated: as infants in hospital are, a priori, more likely to be already suffering from an infection.

3. The type of parenteral infection made no difference to the outcome: the case mortality is the same for all three types.

4. It is not possible to appreciate the true significance of parenteral infection in hospitalcontracted disease without an idea of the composition of the hospital population. This is given in table 8.

Comparing the two tables, it appears that infants with skin or upper respiratory infections, and those without parenteral infection, caught gastro-enteritis in rough proportion to the risk they ran; but there was a strong association with pneumonia. Sufferers from this disease were particularly prone to contract gastro-enteritis. But it must be remembered that pneumonia and gastro-enteritis are both rife during the winter months; so the pneumonia patients were in the wards when the diarrhoeal infection was at its height, whereas the skin sufferers and those with upper respiratory infection were distributed much more uniformly throughout the year.

5. The commonest type of parenteral infection in outside-contracted disease was the upper respiratory. This is, indeed, the commonest infection in infancy, accounting for 24 per cent. of all

TABL: 8

RELATIVE COMPOSITION OF HOSPITAL POPULATION, BASED ON ADMISSIONS AND AVERAGE LENGTH OF STAY

\begin{tabular}{|c|c|c|c|c|c|c|}
\hline & & $\begin{array}{l}\text { Total number of } \\
\text { admissions in } \\
24 \text { months }\end{array}$ & $\begin{array}{c}\text { Percentage } \\
\text { of total }\end{array}$ & $\begin{array}{l}\text { - Average } \\
\text { length of } \\
\text { stay (days)* }\end{array}$ & $\begin{array}{l}\text { Patient-days } \\
\text { spent in } \\
\text { hospital }\end{array}$ & $\begin{array}{c}\text { Percentage } \\
\text { of total }\end{array}$ \\
\hline $\begin{array}{l}\text { Upper respiratory infection } \\
\text { Lower respiratory infection } \\
\text { Septic skin conditions } \ldots \\
\text { Gastro-enteritis } \dagger \text {. } \\
\text { All others (general list) } \ldots\end{array}$ & $\begin{array}{l}\cdots \\
\cdots \\
\cdots \\
\cdots\end{array}$ & $\begin{array}{r}162 \\
99 \\
89 \\
88 \\
236\end{array}$ & $\begin{array}{l}24 \\
15 \\
13 \\
13 \\
35\end{array}$ & $\begin{array}{l}17 \\
27 \cdot 8 \\
38 \\
31 \cdot 5 \\
18 \cdot 9\end{array}$ & $\begin{array}{l}2,754 \\
2,752 \\
3,382 \\
2,772 \\
4,460\end{array}$ & $\begin{array}{l}17 \\
17 \\
21 \\
17 \\
28\end{array}$ \\
\hline Total & . & 674 & 100 & & 16,120 & 100 \\
\hline
\end{tabular}

- The length of stay for gastro-enteritis patients is the average between stay of recovered cases, 46 days, and of fatal cases, 16.5 days.

The importance given to gastro-enteritis in this table has been under-estimated, for no account has been taken of the large number of cases of this disense contracted in hospital. 
infant admissions, and it was present in nineteen out of seventy-nine admissions for gastro-enteritis, that is in 24 per cent. It seems possible that a random sample of the population of the area would show that one in every four infants was suffering from a 'cold-in-the-head.' It is hard to see in this association any etiological factor, particularly as the mortality of gastro-enteritis with upper respiratory infection is three out of nineteen, or 16 per cent., while it is 29 per cent. in the absence of parenteral infection, a significant difference.

6. The high mortality of gastro-enteritis in the puny infant, admitted because it was not getting on well, is very striking. Only one survived out of eleven who contracted enteritis.

Many factors affect the reliability of these two tables, and too much stress should not be placed on inferences drawn from them. It happened frequently that an infant admitted with one infection (or with none) contracted another: the enteric infection is not unique in this respect ! It happened too, that an infant was quite cured of its primary infection, and was about to leave hospital, when it contracted diarrhoea; this is particularly relevant to the long convalescence after pneumonia. The primary infection can hardly be held responsible for the subsequent enteritis. Nevertheless, the following conclusions seem justified: (1) parenteral infection is common in hospital-contracted diarrhoea, but only in so far as the population at risk already suffers from such infection; (2) the type of parenteral infection has no effect on the mortality; (3) and the enteritis is milder than in those without parenteral infections. Remembering that parenteral infection is present also in the population generally, though to a less extent than in hospital, the same conclusions seem to hold for enteritis contracted outside hospital.

In this series, at all events, there appears no causal relationship between enteritis and parenteral diarrhoea. This is not to say that diarrhoea is never caused by parenteral infection; but when it is so caused the enteritis is mild, and is nosologically different from the severe gastro-enteritis here discussed.

\section{Chemotherapy}

Additional evidence about the nature of the infecting agent is given by its response to chemotherapy. It is important to distinguish between the specific dysenteries, and non-specific enteritis : opinion is united in acclaiming the sulpha-drugs in the former group, but is at variance when discussing the latter. Anderson (1941) thought that sulphathiazole was of value, but his cases are few and the disease mild. Taylor (1941) agrees with him, as do Halpern and Cunningham (1942), but Cooper et al. (1941) found it useless in non-specific enteritis. It is interesting to see that no pathogen was found in five out of the six fatal cases in their series. Meyer (1943) reports very favourably on sulphathiazole and sulphaguanidine; however, he considers half his cases at least to be due to Shigella infections. Henderson (1943) found sulphaguanidine of great value in infantile diarrhoea of all types, so does Tudor (1942). On the other hand, Rubens et al. (1943) state that, while chemotherapy was very useful in dysentery cases, it was of no significant avail in non-specific cases. Menchaca (1944) used sulphadiazine on a few cases with good results, as did Tudor (1943) with sulphadiazine and sulphapyrazine. Twyman and Horton (1943) found sulphasuxidine of value in a small series; they do not discuss bacteriology. Marshall et al. (1941) used sulphaguanidine on sixteen dysentery patients with good results, and on three non-specific cases with indifferent results. Burns and Gunn (1944) obtained equivocal results with sulpha-drugs and penicillin in enteritis with severe otitic complications; Gunn (1944b) obtained no improvement with sulphaguanidine or sulphasuxidine, but recommends the use of a soluble sulpha-drug to combat any concomitant respiratory infection. Anderson and Nelson (1944) used sulphasuxidine in an outbreak of diarrhoea among seventy-six infants. They are reluctant to lay much stress on its value, for some patients needed long courses before they improved, and others actually contracted the disease while on full doses of the drug. High et al. (1946) found both sulpha-drugs and penicillin useless in neonatal diarrhoea. The value of both the soluble and insoluble sulpha-drugs in dysentery is admitted by all these investigators, as it has been in adult medicines. But it is plain that in severe non-specific enteritis their value is dubious. The impression left after reading these accounts is that in severe gastroenteritis chemotherapy is of no avail. The present series was treated in the early days of sulphonamide treatment, and the relatively insoluble preparations were not in general use. Sulphapyridine was very frequently used for respiratory infections, and it was no uncommon occurrence for an infant to develop enteritis while taking this drug. This experience agrees with the findings in the literature, that the soluble sulphonamides are useless in non-bacterial enteritis.

\section{Value of Blood and Blood Products}

There is some evidence that blood and bloodproducts are of particular value in infantile enteritis. Felsen and Wolarsky (1941) used lyophile plasma and found it very effective; Lyon and Folsom (1941) found that citrated blood from patients recovering from influenza was very effective, while that from non-influenza sufferers was useless. This would indicate that specific immune bodies are concerned. Alexander and Eiser (1944) used plasma freely for shock, and considers its use an important factor in producing their low case mortality. On the other hand, High et al. (1946) found gamma-globulins to be useless. In the present series, transfusions were given to eleven desperately ill infants, and seven recovered. The numbers are small, and the cases are without 
controls, but there remains a strong clinical impression that without transfusion all would have died.

\section{'Epidemic Diarrhoea of the Newborn'}

Reference has frequently been made to 'epidemic diarrhoea of the newborn.' The first account to deal with this as an entity was by Rice et al. in 1937. A further account was given by Frant and Abramson in 1939, and an authoritative statement by them appeared in 1944. Other general descriptions have been given by Lyon and Folsom (1941) and by Felsen and Wolarsky (1942); this last paper includes an excellent bibliography. There is a striking unanimity in all these reports; they present a highly infectious disorder occurring during the first month of life, in maternity nurseries, and other institutions dealing with neonates. The mortality is usually about 45 per cent. and premature babies in particular suffer very heavily. There is no sex difference, no seasonal incidence, and breast feeding does not fully protect. All writers stress that this disease does not occur after the age of twenty-eight days. No protective measure, other than completely closing the institution, is of any avail in stopping the epidemic. These first reports all come from New York, but epidemics have been reported elsewhere: in Philadelphia (Anderson and Nelson, 1944; High et al., 1946); in Los Angeles (Johnson and Rothman, 1940) and in Milwaukee, Wisconsin (Cron et al., 1940). In this last epidemic, no breast-fed baby died.

Accounts of this malady are not confined to the U.S.A. McClure (1943) described four outbreaks in Ontario. In England epidemics have been reported by Craig (1936), Ormiston (1941), Crowley et al. (1941), Bloch (1941), and Sakula (1943). As previously mentioned, one outbreak occurred on the high seas. In this country, too, the findings agree closely, particularly in the failure to implicate a definite pathogen in spite of the obviously infective nature of the disorder. The suggestion has repeatedly been made that a virus is responsible.

At first glance, it does look as though this disease were indeed a true nosological entity, separate and distinct from gastro-enteritis as it appears in the older infant. But further comparison does not bear this out. Both diseases are highly infectious, and can be controlled only by closing the nursery and dispersing its inmates; in neither has a bacterial pathogen been found, and in both a virus is suspected. The clinical description of epidemic diarrhoea of the newborn fits very well the severe type of gastro-enteritis seen by Gairdner in West Middlesex, or that witnessed in North Kensington and described in these articles. There are two main differences; the first of these concerns the age incidence. Naturally, an outbreak occurring in a maternity hospital will involve babies under four weeks old-they are the only ones there. It is hard to see what sudden change occurs in a baby at twenty-eight days to make it immune to a disease to which it was previously so susceptible. The second factor concerns the protection normally afforded by breast feeding. It is plain that a baby only two weeks. old cannot have been breast-fed for six weeks, and so cannot have the protection given by this period of nursing. Putting the comparison another way: if the severe type of hospital-contracted diarrhoea herein described had occurred in a nursery for neonates it would have been indistinguishable from 'epidemic diarrhoea of the newborn,' as already defined. It has already been stressed that infectious gastro-enteritis tends to occur in concentrations of susceptibles; and the highest concentrations of all are to be found in maternity nurseries. It is this fact which has given outbreaks of infectious diarrhoea in such nurseries their apparently unique features. It should be noted that neonates are rarely found in hospitals, other than in maternity nurseries. In the present series, there were only five infants aged one month, and only three younger than that. The hospital has no maternity department, and although from time to time young infants were admitted because their mothers were ill, as a rule they kept well. Such healthy nurslings were not kept in the general children's ward, but in the side-rooms of adults' wards, and probably owe their immunity from infectious diarrhoea to this precaution.

\section{Conclusions}

The following conclusions seem justified:

1. 'Diarrhoea and enteritis under two years' is a heterogeneous group.

2. Most of the severe cases of this group belong to an acute infectious (probably specific) disorder, which carries a case-mortality of 33-50 per cent.

3. This disease occurs in definite small epidemics, at different times in different places, but mainly in early winter.

4. Congregation of susceptibles favours the development of an epidemic; so the disease is found, with increasing frequency, in overcrowded cities, in children's hospital wards, and particularly in the nurseries of maternity hospitals.

5. The pathogen is non-bacterial, and may well be viral. The route of entry is not oral, but probably respiratory. The brunt of the infection falls on the intestine, its regional lymph glands, and the liver.

6. The value of chemotherapy is very doubtful, but blood transfusion seems to exert a specific effect.

7. There is no good evidence that this disease is caused by parenteral infection.

8. There is no good reason for considering 'epidemic diarrhoea of the newborn' to be a separate entity. This term merely describes what happens when severe gastro-enteritis breaks out in a maternity nursery. 
I have to thank Dr. Basil Hood, who was then Medical Superintendent at the Hospital, for facilitating my search of the hospital records; and Sir Allen Daley, Medical Officer of Health, London County Council, for permission to publish these findings.

\section{REFERENCES}

Abramson, H., Frant, S. and Oldenbuisch, C. (1939). Med. Clin. N. Amer., May, p. 591.

Abt, I. A. and Abt, A. F. (1944). In Brennemann's Practice of Pediatrics. W. F. Prior Company, vol. 2, chap. 31, p. 3.

Alexander, M. B. and Eiser, Y. (1944). Brit. med. J., $2,425$.

Anderson, E. V. (1941). J. Pediat., 18, 732.

Anderson, N. A. and Nelson, W. E. (1944). Ibid., 25,319 .

Blacklock, J. W. S., Guthrie, K. J. and MacPherson, I. (1937). J. Path. Bact., 44, 321.

Bloch, E. (1941). Brit. med. J., 1, 151.

Brown, G., Crawford, G. J. and Stent, L. (1945). Ibid., $2,524$.

Buddingh, G. J. (1946). South. med. J., 39, 382.

— and Dodd, K. (1944). J. Pediat., 25, 105.

Burns, E. and Gunn, W. (1944). Brit. med. J., 2, 178.

Campbell, R. M. and Cunningham, A. A. (1941). Arch. Dis. Childh., 16, 211.

Cooper, M. L., Zucker, R. L. and Wagoner, S. (1941). J. Amer. med. Ass., $117 \mathrm{ii}, 1520$.

Craig, W. S. (1936). Lancet, 2, 68.

Cron, R. S., Shutter, H. W. and Lahmann, A. H. (1940). Amer. J. Obst. Gynec., 40, 88.

Crowley, N., Downie, A. W., Fulton, F. and Wilson, G. S. (1941). Lancet, 2, 590 .

Cruickshank, R. (1945). Arch. Dis. Childh., 20145.

- (1946). Proc. roy. Soc. Med., 39, 389.

Department of Health for Scotland (1947). Neonatal Deaths due to Infection. Edinburgh. H.M.S.O., p. 28.

Draper, F. and Brown, G. W. (1946). Med. J. Austral., 1,469 .

Evans, P. (1942). Arch. Dis. Childh., 17, 130.

Feibush, J. S. (1945). N.Y. State J. Med., 45i, 1113.

Felsen, J. and Wolarsky, W. (1941). Arch. Pediat., 58, 751 .

(1942). Ibid., 59, 495.

Fothergill, L. D. (1944). In Brennemann's Practice of Pediatrics. W. F. Prior Company, vol. 2, chap. 5 , p. 13.

Frant, S. and Abramson, H. (1939). N.Y. State J. Med., $39 i, 784$.

(1944). In Brennemann's Practice of Pediatrics. W. F. Prior Company, vol. 1, chap. 28. Sect. II.

Gairdner, P. (1945). Arch. Dis. Childh., 20, 22.

Gunn, W. (1944a). Brit. J. Child. Dis., 41, 1. (1944b). Proc. roy. Soc. Med., 37, 480.

(1946). North-Western Hospital Notes on Acute Gastro-Enteritis. London.
Halpern, S. R. and Cunningham, J. (1942). J. Pediat., $21,184$.

Henderson, J. L. (1943). Brit. med. J., 1, 410.

High, R. H., Anderson, N. A. and Nelson, W. E. (1946). J. Pediat., 28, 407.

Hinden, E. (1940). Lancet, 1, 145.

Hormaeche, E., Surraco, N. L., Peluffo, C. A. and Aleppo, P. L. (1943). Amer. J. Dis. Child., 66, 539.

Johnson, B. B. and Rothman, P. E. (1940). Calif. West. Med., 52, 229.

Light, J. S. and Hodes, H. L. (1943). Amer. J. Publ. Hlth., 33, 1451.

Lyon, G. M. and Folsom, T. G. (1941). Amer. J. Dis. Child., 61, 427.

McClure, W. B. (1943). J. Pediat., 22, 60.

Marriott, W. McK. (1944). In Brennemann's Practice of Pediatrics. W. F. Prior Company, vol. 1, chap. 28 , p. 4.

Marshall, E. F., Bratton, A. C., Edwards, L. B. and Walker, E. (1941). Bull. Johns Hop. Hosp., 68,94 .

Menchaca, F. J. (1944). Amer. J. Dis. Child., 68, 5.

Meyer, L. F. (1943). Acta. med. Orient., 2, 73.

Mitman, M. (1944). Proc. roy. Soc. Med., 37, 482.

Moore, J. L. and Dennis, E. W. (1940). J. Lab. clin. Med., $25,955$.

Neter, E. R. (1944). Amer. J. Dis. Child., 68, 312.

Neter, E. R. and Clark, P. (1944a). Amer. J. Digest. Dis., 11, 356.

_- (1944b). Ibid., 11, 323.

- and Farrar, R. H. (1943). Ibid., 10, 344.

Ormiston, G. (1941). Lancet, 2, 588.'

Ouyang, G. (1940). Chinese med. J., 58, 456.

Paterson, D. (1933a). In Diseases of Infancy and Childhood. Ed. Parsons and Barling. Oxford Medical Publications, London, 1, 758.

(1933b). Ibid., 774.

(1944). In Sick Children, Diagnosis and Treatment. Cassell and Co. London, p. 102 et seq.

Reimann, H. A. (1944). Arch. intern. Med., 74, 280 (see p. 303).

- Hodges, J. H. and Price, A. H. (1945). J. Amer. med. Ass., 127, 1.

—-, Price, A. H. and Hodges, J. H. (1945). Proc. Soc. exp. Biol. N.Y., 59, 8.

Rice, J. L., Best, W. H., Frant, S. and Abramson, H. (1937). J. Amer. med. Ass., $109,475$.

Rubens, E., Kaplan, M., Borovsky, M. P. and Blatt, M. L. (1943). J. Pediat., 22, 70.

Sakula, J. (1943). Lancet, 2, 758.

Smellie, J. M. (1939). Ibid., 1, 969 and 1026.

Taylor, G. (1941). J. Pediat., $18,469$.

Tudor, R. B. (1942). Ibid., 20, 707.

- (1943). Ibid., 22, 652.

Twyman, A. H. and Horton, G. R. (1943). J. Amer. med. Ass., 123, 138.

Wakcher, D. N. (1946). J. clin. Invest., 25, 103.

Weihl, C., Rapoport, S. and Dodd, K. (1947). J. Pediat., 30, 45. 